\title{
An Exploration on the Relationship of Transformational leadership, Innovation Atmosphere and E-Commerce Organization Innovation
}

\author{
Mian Lin \\ Asia University, Taichung City, Taiwan, PRC \\ Email: nikkidk120@gmail.com
}

Received May 2014

\begin{abstract}
In the knowledge economy, the innovation already became the motivation of foundation for organization growth, especially for E-commerce organizations. Business organizations should consider how their organizational innovations for all aspects of resource optimization to increase efficiency. The purpose of this study is to build some conceptual models in transformational leadership, innovation atmosphere and E-commerce organization innovation. Through the questionnaire survey procedure in some E-commerce corporations in Zhe Jiang, this research takes correlation analysis and regression analysis. We discovered: both transformational leadership and innovation atmosphere have the remarkable influence on E-commerce organization innovation. We also find the differences of effects and their interactions directly between the transformational leadership, innovation climate and the dimension degrees on E-commerce organization innovation.
\end{abstract}

\section{Keywords}

Transformational Leadership, Innovation Atmosphere, E-Commerce Organization Innovation

\section{Introduction}

The 21st century is the era of knowledge economy, innovation will be as the basis for progress in organization's sustainable development, and the market competition also has become fiercer. Especially, E-commerce organizations are facing more uncertainly challenges. However, how to adapting to the new situation or improving organizational capability and effectiveness? The innovation is played a remarkable role. But, how to maintain the innovation level of organization? What are the factors that affect directly innovation? In the whole innovation process, the first resource comes from leader; the leadership style will be also the important indicator in organi- 
zational innovation. Previous studies have also pointed out that leadership style is the biggest environmental factor affecting achievements of subordinates, morale and satisfaction, which also is one of variables of affecting the achievements of an organization. During the past 20 years, some researchers think the innovation climate have gradually become more and more important. Ekvall \& Ryhammar's study found that atmosphere of an organization is mainly in the charge of the leadership behavior, culture and values of it [1]. This research is starting from the leadership style and study the correlation between transformational leadership and innovative atmosphere of an organization. Assuming transformational leadership style is a variable, this paper analyzed whether it influences E-commerce organization innovation or not. Then assumed innovation climate be another variable, observing the relevance of various dimensions. Thus, it provides references to executives' control and adjustment of leadership style in practice of management.

\section{Theoretical Background and Hypotheses}

\subsection{Transformational Leadership Style}

Transformational leadership belongs to a factor of leadership and is a leadership behaviour that inspires his subordinates to make performance which exceed the expectation [2]. Integrating belief in one's ability and forming positive feelings is concerned by transformational leadership [3]. This understanding indicates that the leader is clear about principal value and task in the organization as well as the final objective the enterprise determine to fulfill [4]. Transformational leaders encourage followers to view problems from new perspectives (intellectual stimulation), provide support and encouragement (individualized consideration), communicate a vision (inspirational motivation), and engender emotion and identification (charisma), while transactional leaders motivate subordinates through the use of contingent rewards, corrective actions (passive management by exception), and rule enforcement (active management by exception) [5]. "Transformational leadership style scale", developed by B. J. Avolio, is adopted during the measurement of Transformational leadership dimensions. This scale is divided into idealized influence, inspiration motivation, intellectual stimulation, individualized consideration [6].

\subsection{Organizational Innovation Atmosphere}

Research on the organizational innovation atmosphere began in the 1960s. Some relevant scholars (for example: Ekvall, Iisaksen, Amabile, Britz, Tesluk) expounded their own views respectively for the definition of organizational innovation atmosphere [7] [8], while Chinese scholars also gave their opinions in succession. Scholars Liu Yun and Shi Jintao think that organizational innovation atmosphere is a perception of organization members support organization environmental innovation [9]. Chen Baojie thinks that the trait of organization innovation atmosphere is that organization should have a kind of atmosphere in which everyone believes innovation is an opportunity, not a threat. Individuals with creative potential are willing and able to release their potential to promote the organizational innovation performance [10]. Through in-depth analysis and talking with some relevant scholars and the key position employees, this dissertation has designed an organizational innovation atmosphere questionnaire of E-commerce organization from scholars Liu Yun and Shi Jintao's scale. Because this scale is based on our country's actual situation. In the questionnaire, the design of the options used by five categories (specific dimensions: manager support, organization concept, team support, resource supply, task characteristic) [9].

From the arguments bring forth above, we specify the following hypotheses to focus our empirical investigation.

Hypothesis 1: Transformational leadership is positively related to innovation atmosphere.

Hypothesis 2: Transformational leadership is related to E-commerce organization innovation.

Hypothesis 3: Innovation atmosphere is related to E-commerce organization innovation.

Hypothesis 4: Innovation atmosphere change mediates the relationship between transformational leadership and E-commerce organization innovation.

\section{Methods}

\subsection{Scale Design}

Measurement of competent leadership style is on the basis of the multi-factor leadership questionnaire (MLQ) 


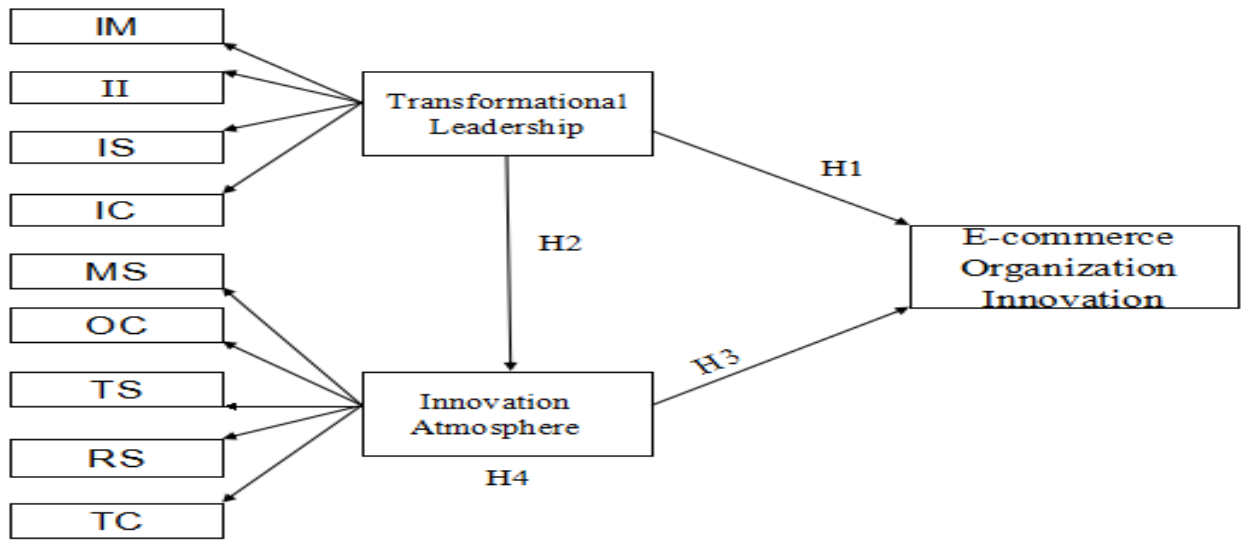

Figure 1. Research model.

complied by Bass, also combine B. J. Avolio's research, This scale is used for measuring transformational leadership is divided into idealized influence, inspiration motivation, intellectual stimulation, individualized consideration. The questionnaire in this study used five-point scale of Likert-type, and the descriptions of the behavior of each question from low to high level of knowledge are divided into "never," "rarely," "sometimes," "frequently" and "always" five levels, which tried to be chosen in turn by actual cognitive degree of transformational leadership style.

"Organizational innovation atmosphere assessment scale in china", developed by scholars Liu Yun and Shi Jintao, is adopted during the measurement of Organizational innovation atmosphere. In the questionnaire, the design of the options used by five category: manager support, organization concept, team support, resource supply, task characteristic) The five-point scale of Likert-type is also adopted during this measurement, and respectively is "never," "rarely," "sometimes," "frequently" and "always" five levels, which tried to be chosen in turn by actual cognitive degree of organizational innovation climate.

"E-commerce organizational innovation scale" modified by the scale of Educational Organization innovation measurement mainly refers to the study of the Wang's. The five-point scale of Likert-type is also adopted during this measurement, and respectively is "never," "rarely," "sometimes," "frequently" and "always" five levels, which tried to be chosen in turn by actual cognitive degree of organizational innovation climate

\subsection{Sample}

This study focused on the relationship between leadership style and innovation atmosphere in E-commerce organization, its scope of investigation is region of Zhe Jiang. We select 34 E-commerce organizations to analyze. Because of having better research cooperation with the companies mentioned above, we adopted a way of door-to-door investigation. In total, 350 questionnaires were distributed, 298 questionnaires were returned. By deleting those duplicate or incomplete data, fifty-five percent raters were female. Most of the raters (56\%) are general staff, Five of the selected organizations are foreign wholly owned enterprises; eight of them are joint ventures; two of them are state-owned companies; nineteen of them are private enterprises. With regard to the organizational size, three of the selected organizations own over 500 employees; others own less 500 employees.

\section{Results}

We first ran a preliminary statistic analysis with all of the survey items to test the scales' psychometric properties. Deleting some items by factor analysis, we still retain 9 items for transformational leadership, 5 items for Innovation atmosphere. Coefficient of each variable was over 0.82 , which indicated the questionnaire used had good reliability.

Table 1 shows descriptive statistics and intercorrelations among the scales.

1. Every dimension of transformational leadership and E-commerce organization innovation were significantly positive correlated.

2. Dimensions of innovation atmosphere and E-commerce organization innovation were significantly positive correlated. 
Table 1. Descriptive statistics and intercorrelations among scale $(\mathrm{N}=298)$.

\begin{tabular}{|c|c|c|c|c|c|c|c|c|c|c|c|c|}
\hline Variables & 1 & 2 & 3 & 4 & 5 & 6 & 7 & 8 & 9 & 10 & 11 & 12 \\
\hline \multicolumn{13}{|l|}{ Transformational leadership } \\
\hline Idealized influence & $0.975^{* *}$ & & & & & & & & & & & \\
\hline Individual consideration & $0.945^{* *}$ & $0.876^{* *}$ & & & & & & & & & & \\
\hline Inspiration motivation & $0.900^{* *}$ & $0.832^{* *}$ & $0.787^{* *}$ & & & & & & & & & \\
\hline Intellectual stimulation & $0.978^{* *}$ & $0.946^{* *}$ & $0.911^{* *}$ & $0.855^{* *}$ & & & & & & & & \\
\hline Innovation atmosphere & $0.765^{* *}$ & $0.691^{* *}$ & $0.765^{* *}$ & $0.721^{* *}$ & $0.733^{* *}$ & & & & & & & \\
\hline Manager support & $0.754^{* *}$ & $0.735^{* *}$ & $0.721^{* *}$ & $0.705^{* *}$ & $0.718^{* * *}$ & $0.888^{* *}$ & & & & & & \\
\hline Organization concept & $0.746^{* *}$ & $0.656^{* * *}$ & $0.742^{* *}$ & $0.690^{* * *}$ & $0.735^{* *}$ & $0.926^{* *}$ & $0.836^{* *}$ & & & & & \\
\hline Team support & $0.678^{* *}$ & $0.588^{* *}$ & $0.718^{* *}$ & $0.654^{* *}$ & $0.633^{* *}$ & $0.839^{* *}$ & $0.706^{* *}$ & $0.733^{* *}$ & & & & \\
\hline Resource supply & $0.735^{* *}$ & $0.678^{* *}$ & $0.720^{* *}$ & $0.691^{* *}$ & $0.708^{* *}$ & $0.942^{* *}$ & $0.776^{* *}$ & $0.863^{* *}$ & $0.791^{* *}$ & & & \\
\hline Take characteristic & $0.602^{* *}$ & $0.545^{* *}$ & $0.581^{* *}$ & $0.595^{* *}$ & $0.571^{* *}$ & $0.930^{* *}$ & $0.769^{* *}$ & $0.783^{* *}$ & $0.816^{* *}$ & $0.871^{* *}$ & & \\
\hline E-commerce innovation & $0.786^{* *}$ & $0.766^{* *}$ & $0.788^{* *}$ & $0.745^{* *}$ & $0.728^{* *}$ & $0.885^{* *}$ & $0.766^{* *}$ & $0.779^{* *}$ & $0.812^{* *}$ & $0.901^{* *}$ & $0.790^{* * *}$ & \\
\hline
\end{tabular}

Table 2. Regression results (transformational leadership and innovation atmosphere).

\begin{tabular}{cccccc}
\hline & \multicolumn{4}{c}{ Independent variables } \\
\cline { 2 - 6 } dependent variables & Transformational leadership & Idealized influence & $\begin{array}{c}\text { Individualized } \\
\text { consideration }\end{array}$ & $\begin{array}{c}\text { Inspiration } \\
\text { motivation }\end{array}$ & $\begin{array}{c}\text { Intellectual } \\
\text { stimulation }\end{array}$ \\
\cline { 2 - 6 } Innovation atmosphere & $6.689^{* *}$ & $5.392^{* *}$ & $6.534^{* *}$ & $5.976^{* *}$ & $6.072^{* *}$ \\
Adjusted $\mathrm{R}^{2}$ & 0.853 & 0.475 & 0.571 & 0.527 & 0.536 \\
$\Delta \mathrm{F}$ & 44.742 & 28.051 & 42.776 & 35.694 & 36.854 \\
\hline
\end{tabular}

3. Dimensions of innovation atmosphere and transformational leadership were significantly positive correlated. It indicates the level of transformational leadership style higher, the innovation atmosphere will be better.

\section{Hypotheses Test}

(1) The relationship between transformational leadership and innovation atmosphere

Assume four dimensions of transformational leadership be independent variables, innovation atmosphere be dependent variables, calculate by regression analysis (Table 2). The result shows transformational leadership has a positive relationship with innovation atmosphere. We can see that hypothesis of $\mathrm{H} 1$ is supported by empirical data.

(2) The relationship between transformational leadership and E-commerce organization innovation

Assume four dimensions of transformational leadership be independent variables, E-commerce organization innovation be dependent variables, calculate by regression analysis (Table 3). The result shows transformational leadership has a positive relationship with E-commerce organization innovation. We can see that hypothesis of $\mathrm{H} 2$ is supported by empirical data.

(3) The relationship between innovation atmosphere and E-commerce organization innovation

Assume five dimensions of innovation atmosphere be independent variables, E-commerce organization innovation be dependent variables, calculate by regression analysis (Table 4 below). The result shows innovation atmosphere has a positive relationship with E-commerce organization innovation. We can see that hypothesis of $\mathrm{H} 3$ is supported by empirical data.

(4) The mediator-innovation atmosphere

In the model 1, assume transformational leadership be independent variables, results shows transformational 
leadership has a positive relation with innovation atmosphere. In the model 2, assume transformational leadership be independent variables, results shows transformational leadership has a positive relation with E-commerce organization innovation. In the model 3, assume innovation atmosphere be independent variables, results shows innovation atmosphere has a positive relation with E-commerce organization innovation. In the model 4, assume transformational leadership and innovation atmosphere be independent variables, results shows both transformational leadership and innovation atmosphere has a positive relation with E-commerce organization innovation, but the regression coefficient become lower, that indicates innovation atmosphere has a mediating effect (Table 5). Thus, hypotheses 4 is supported.

\section{Conclusion}

The empirical results show that transformational leadership style and innovation atmosphere both have highly positive correlation with E-commerce organization innovation. The innovation atmosphere has a mediating effect between transformational leadership and E-commerce organization innovation, according to previous literature, which means transformational leaders should use power wisely and situational factors to motivate employees' willing and ability to innovative and change and to give subordinates authority to help them develop-

Table 3. Regression results (transformational leadership and E-commerce organization innovation).

\begin{tabular}{|c|c|c|c|c|c|}
\hline \multirow{2}{*}{$\begin{array}{c}\text { dependent } \\
\text { variables }\end{array}$} & \multicolumn{3}{|c|}{ Independent variables } & \multirow[b]{2}{*}{$\begin{array}{l}\text { Inspiration } \\
\text { motivation }\end{array}$} & \multirow[b]{2}{*}{$\begin{array}{l}\text { Intellectual } \\
\text { stimulation }\end{array}$} \\
\hline & Transformational leadership & Idealized influence & $\begin{array}{c}\text { Individualized } \\
\text { consideration }\end{array}$ & & \\
\hline $\begin{array}{c}\text { E-commerce } \\
\text { organization } \\
\text { innovation }\end{array}$ & $7.171^{* *}$ & $6.714^{* *}$ & $6.381^{* *}$ & $6.316^{* *}$ & $6.172^{* *}$ \\
\hline Adjusted $\mathrm{R}^{2}$ & 0.5913 & 0.562 & 0.546 & 0.517 & 0.530 \\
\hline$\Delta \mathrm{F}$ & 51.441 & 45.094 & 40.706 & 39.845 & 38.224 \\
\hline
\end{tabular}

Table 4. Regression results (innovation atmosphere and E-commerce organization innovation).

\begin{tabular}{|c|c|c|c|c|c|c|}
\hline \multirow{2}{*}{$\begin{array}{c}\text { dependent } \\
\text { variables }\end{array}$} & \multicolumn{3}{|c|}{ Independent variables } & \multirow[b]{2}{*}{ Team support } & \multirow[b]{2}{*}{ Resource supply } & \multirow[b]{2}{*}{$\begin{array}{c}\text { Task } \\
\text { characteristics }\end{array}$} \\
\hline & Innovation atmosphere & Manager support & $\begin{array}{c}\text { Organizational } \\
\text { concept }\end{array}$ & & & \\
\hline $\begin{array}{l}\text { E-commerce } \\
\text { organization } \\
\text { innovation }\end{array}$ & $10.675^{* *}$ & $6.721^{* *}$ & $6.858^{* *}$ & $7.852^{* *}$ & $11.765^{* *}$ & $7.355^{* *}$ \\
\hline Adjusted $\mathrm{R}^{2}$ & 0.7743 & 0.558 & 0.587 & 0.678 & 0.807 & 0.618 \\
\hline$\Delta \mathrm{F}$ & 113.961 & 45.144 & 47.746 & 61.677 & 138.24 & 54.21 \\
\hline
\end{tabular}

Table 5. Regression results (mediating effect).

\begin{tabular}{|c|c|c|c|c|}
\hline \multirow{2}{*}{$\begin{array}{l}\text { dependent } \\
\text { variables }\end{array}$} & \multicolumn{3}{|c|}{ Independent variables } & \multirow[b]{2}{*}{ Model 4} \\
\hline & Model 1 & Model 2 & Model 3 & \\
\hline & Innovation atmosphere & E-commerce innovation & E-commerce innovation & E-commerce innovation \\
\hline $\begin{array}{l}\text { Transformational } \\
\text { leadership }\end{array}$ & $10.675^{* * *}$ & $7.172^{* * *}$ & & $2.186^{* * *}$ \\
\hline $\begin{array}{l}\text { innovation } \\
\text { atmosphere }\end{array}$ & & & $10.675^{* * *}$ & $5.626^{* * *}$ \\
\hline $\mathrm{R}^{2}$ & 0.781 & 0.616 & 0.781 & 0.81 \\
\hline$\Delta \mathrm{F}$ & 113.961 & 51.441 & 113.961 & 66.906 \\
\hline
\end{tabular}


their potential to achieve organizational goals. It can propose the following recommendations for the high-level managers. First, the leaders should introduce emotional quotient (EQ) in the leadership process to make themselves more attractive. In this way, when improving leadership efficiency and creating enterprise's high performance, improving employee innovation. Second, the leaders should take care of the needs of employees, and make timely exchange and communication with them, encourage employees to innovate more. Third, the leaders could, through intellectual stimulation, encourage employees to think independently, to make use of new methods to complete the task and to appreciate a sense of accomplishment in the work. Finally, the leaders can also use inspirational motivation to effectively convey the organization's vision to the employees, so that they will look forward the future development in optimism and hope, and thus produce a strong working motivation and a high motivation atmosphere.

\section{References}

[1] Ekvall, G. and Ryhammar, L. (1999) The Creative Climate: Its Determinants and Effects at a Swedish University. Creativity Research Journal, 12, 303-310. http://dx.doi.org/10.1207/s15326934crj1204_8

[2] Ylimaki, R.M. (2006) Toward a New Conceptualization of Vision in the Work of Educational Leaders: Case of Visionary archetYpe. Educational Administration Quarterly, 42, 620-651. http://dx.doi.org/10.1177/0013161X06290642

[3] Bass, B.M. (1999) Two Decades of Research and Development in Transformational Leadership. European Journal of Work and Organizational Psychology, 8, 9-32. http://dx.doi.org/10.1080/135943299398410

[4] Kaur, G. and Kainth, G.S. (2010) Job Satisfaction: A Challenging Area of Research in Education. Munich Personal RePEc Archive, 1-29.

[5] Bass, B.M. and Avolio, B.J. (1990) Developing Transformational Leadership: 1992 and Beyond. Journal of European Industrial Training, 14, 21-27. http://dx.doi.org/10.1108/03090599010135122

[6] Avolio, B.J. (1998) Full Leadership Development: Building the Vital Forces in Organization. Transformational Leadership: Industy, Military, and Educational Impact, Mahwah, NJ. Lawrence Erlbaum, 43-49.

[7] Drucker, P.F. (1998) The Discipline of Innovation. Harvard Business Review, 149-157.

[8] Amabile, T. M. (1997) Motivating Creativity in Organizations. California Management Review, 40, 22-26.

[9] Liu, Y. and Shi, J.T. (2009) The Development of Organizational Innovative Atmosphere Questionnaire Based on Key. Industrial Engineering and Management, 14, 105-107. (in Chinese)

[10] Chen, B.J. (2008) Organizational Innovation Atmosphere and Measurement. Team Management, 92-96. (in Chinese) 